\title{
Teachers' Use of Textbooks: practice in Namibian science classrooms
}

\author{
FRED LUBBEN \& BOB CAMPBELL \\ Department of Educational Studies, University! of York, Heslington, York YO10 \\ SDD, UK

\section{CHOSHI KASANDA, HILENI KAPENDA, NOAH GAOSEB \& UTJI KANDJEO-MARENGA} \\ Department of Mathernatics, Science and Sport Education, University of Namibia, \\ Namibia
}

\begin{abstract}
SUMMARY Incidences of prescribed textbook usage in science classrooms in Nambia have been analysed using an approach adapted from linguistic analysis. Aspects of pedagogic purpose, text genre, and the social interactions between teachers and learners were used to characterise teacher and learner engagement with textbooks, and thus categorise their usage in relation to a national policy of learner-centred education. Results indacate a teacher dominated textbook use and a low frequency. and restricted range of texbook references per lesson, with some 40\% of the Senior Secundary classes obseried makmg no use of their textbook in class. The major uses of textbooks in class were for diagrams and data, and to verify factual information. Occasionally, questions in textbooks were used as homework to test and or consolidate knowledge. Pupils rarely initiated a reference to a textbock. It is suggested that if leartiers are to benefit fully from the inviestment in textbooks then their teachers need to be helped to use the resource in more constructize ways.
\end{abstract}

\section{Introduction}

In the industrialised world, the benefits of school textbooks as classroom resources are seldom queried and a recent study in the UK has confirmed the direct relationship between expenditure on textbooks and learners' achievement (Watson, 2000). Linked to this, Haggarty \& Pepin (2002) have raised a concern about the restricted access that pupils in England have to mathematics textbooks and the resultant impact on learning outcomes. For the developing world, international surveys show that the provision of textbooks ranks amongst the five most cost-effective ways of improving achievement of learners (Verspoor, 1991). Consequently, considerable donor and government investment is put into the provision of pupil textbooks for schools in developing countries. Namibia is no exception, but what do we know about the ways textbooks make their impact? 


\section{F. Lubben et al.}

Weinbrenner (1992) identifies three areas of school textbook research. First, process-orientated research that focuses on the lif ecycle of schoolbooks, i.e. their development, approval, distribution, access, introduction and disposal. For the current study, access to textbooks is of particular importance. In the UK, as in many other industrialised countries, most learners have access to one of a class set of textbooks protided by the school but, in about a quarter of classrooms, textbooks are shared by leamers (Johnson, 1999; Lambert, 1999). Depending on the subject, between half and two-thirds of secondary school learners are loaned a textbook to take home to use for homework and revision. Most education ministries in Southern Africa aim to provide one prescribed textbook for each subject on free loan to every learner (Da Cruz et al., 2000), but some countries have instituted textbook rental schemes or direct purchasing for the better-of families. Even with a free textbook system, in reality textbook possession is not universal. In Namibia Van Graan et al. (2002) report that only $62 \%$ of the pupils in senior primary classes have their own textbook for mathematics and English. In neighbouring South Africa, Howie (2001) reports that the headteachers of $45 \%$ of secondary schools surveyed indicated that the progress of their learners in science and mathematics is hampered by a lack of textbooks.

Weinberger's (1992) second area of research on school textbooks is productorientated research that explores the textbook as a teaching medium and as a means of visual communication. Product-orientated textbook research is helpful to curriculum designers and facilitates the provision of more appropriate resources to support the curriculum. This area includes research into gender and cultural sensitivity, and readability of textbooks. Some such studies of the readability of science textbooks have focused on learners for whom English is a second language (ESL). These studies have shown that language levels used in prescribed texts is of ten above the reading level of the learners (Ryf \& Cleghorn, 1997 ). It also shows that widely reported problems with understanding nontechnical words (like constant, independent, device or displace) apply equally to ESL learners in Britain and in Southern Africa (Prophet \& Towse, 1999).

More generally, Kearsey \& Turner (1999) used genre analysis to study the issue of ESL learners' access to science textbooks. They found that such learners have problems switching from everyday English (often used in topic introductions) to the more scientific genres used in subsequent sections.

Weinbrenner's (1992) third area is reception-orientated school textbook research where 'schoolbooks are examined as an independent socialisation factor in teaching with regard to their effect on teacher and pupil' (p. 23). Kuhn (1970) suggested that a university (or school) textbook conveys the contemporary paradigm of the subject and of the pedagogy, providing a way of socialising novices into the budy of knowledge and the processes specific to the subject. Stray (1994) emphasises the additional socio-economic values conveyed by textbooks, and sees then as market commodities. Thus, textbooks play a key role in the transmission of 'multiply coded' cultural meaning, about the field of knowledge (what should be learned), about pedagogy (how the field of knowl- 
cdge should be taught and learned), and about the capitalist system of production and consumption. The complex coding explains the different interpretatıons made by teachers and learners of the meanings conveyed by a textbook. By contrast Olson (1989) claims, however, that the intention of a textbook is to report meaning that is highly crystallised and singularly interpretable. He states that:

Although never completely successful, [school] texts are attempts to construct statements in which the literal meaning is an adcquate reflection of the speaker's intention, and which, as a result preserve their meaning across speakers and situations. (p. 237).

Luke et al. (1989) take issue with this interpretation of the role of the textbook and emphasise "the crucial difference between the "text per se" and the "text in use". more specifically: the text in use in the rulc bound classroom" (p. 250, their emphasis). They argue that the learner does not engage with the textbook on his or her own terms in a classroom, but experiences the textbook as a support to their learning as mediated by the teacher. Prior to its use in class the teacher will have made decisions about the role allocated to the textbook in learning activities.

However, while there is literature proclaiming the value of textbooks and providing theoretical perspectives on their use, despite the importance attached to textbooks, and the large investments made in their production and purchase, few empirical studies have been reported on the use of textbooks in class situations and their mediation by teachers (Haggarty \& Pepin, 2002). In a questionnaire-based study Zahorik (1991) related the teaching styles of over 100 American clementary, middle and secondary school teachers to their use of textbooks. All were asked to provide a plan of activities for a lesson on urbanisation and were provided with a copy of a relevant textbook chapter for potential use. Just over half the teachers planned to have students interact with the text (usually reading aloud or silently) in class. The vast majority of these teachers had a 'coverage' teaching style, characterised by starting with an overview of the topic and definitions of terms, then devcloping through text reading to conclude with a general discussion of the text. By contrast, the other teachers did not plan to use the textbook chapter in class but intended to use other stimuli. Most of these teachers had a 'thinking' teaching style, characterised by discussing student ideas related to the topic as a starting point, developing the concepts through a problem solving activity or presentation and ending with small-group investigations. Although the study presented teachers with a hypothetical situation, rather than observe them in class, the finding that the use of a textbook in class is linked to a teaching style is consistent with that of an observation study of primary mathematics classrooms in Kenya by Merritt (1992). Here, it was concluded that teachers using a drill and practice and rote learning approach were heavily dependent on the text, but did not exploit it to highlight the main points for the learners. In contrast, teachers who used an oral 


\section{F. Lubben et al.}

and interactive teaching style made little reference to the textbook, and when they did so it was mainly for homework and assessment tasks.

The power of the science textbook is illustrated in two studies of different learning methods in Senior Secondary science, i.e. practical work and collaborative concept mapping. An Australian (observational) study (Milne et al., 2002) of small groups examıning and drawing the parts of a eucalyptus flower describes two girls observing carefully and recording accurately in their note books what they see. However, since the number of petals on their specimen and thus in their drawings, differs from the generalised diagram of the flower in their textbook, they decide to erase their representation and copy the textbook version: 'Clearly Jane and Fiona did not value their voice in science. Instead, they bowed to the voice of the textbook' (p. 118). In a second (experimental) study, the quality of group interactions of groups of Dutch physics students (Van Boxtel et al., 2000) was traced, whilst they developed a concept map for current electricity. Half of the groups was provided with textbooks, the other half was not. The availability of the textbooks had a negative influence on the quality of group interaction, decreasing verbal elaboration and collective construction of meaning. This, in turn, had a negative influence on individual learning outcomes. In both studies, the perceived authority of the textbook interfered with knowledge construction.

The study reported in this paper focuses on how science teachers use textbooks in Junior and Senior Secondary classes in Namibia. Namibia is a young country just 12 years in to independence with an ongoing programme of development and improvement of educational practice underpinned by a strong philosophy of learner-centered education. Like in many other sub-Saharan countries (Da Cruz et al., 2000), the Namibian Ministry of Education prescribes, buys and distributes textbooks to schools. Schools then make texts available on loan to their learners. This system is reported to function well (Tjikuua, 2000). However, a major evaluation of the education system in the country recommends that 'at secondary level the transfer of the cost of textbooks and materials to the learner could be immediately implemented. The introduction of such charges on a gradual basis could free a great deal of resources for investment in the education system' [Government of the Republic of Namibia (GRN), 1999, p. 77]. While not the driving force of this study, it is important to the contextualisation of the research. The main reason for conducting the study was to obtain some baseline field data to help to inform science teacher education programmes and curriculum development initiatives with the aim of maximising the potential impact of science textbooks. This need is set against the background of a young country that recognises that it is still developing a sufficient cadre of adequately educated and trained secondary school science teachers.

The research questions posed in this study are as follows:

- how often do science teachers in Namibia use the prescribed textbooks in their classroom teaching? 
- what are science teachers' apparent purposes for using the prescribed textbooks in their teaching?

- how does the usc of the prescribed textbooks differ for Junior and Senior classes?

\section{Research Methods}

Data on classroom activities were collected in 15 biology and 14 physical science lessons spanning grades 10,11 and 12 for 12 teachers in six schools in various areas of Namibia. Grade 10 is the last grade of the Junior Secondary phase while grades 11 and 12 comprise the Senior Secondary level. The sample included urban, peri-urban and rural schools. All teachers (nine female and three male) were qualified to teach Junior Secondary science (holding a teaching diploma or other qualification). All were recently enrolled in the Mathematics and Science Teacher Extension Programme (MASTEP). This programme provides structured INSET to upgrade teachers' content knowledge and pedagogy to prepare them to teach Senior Secondary classes leading to the International General Certificate of Secondary Education (IGCSE).

Three data collection methods were used. First, oral classroom exchanges were recorded by an audio-tape-recorder placed near the front of the class. Secondly, a non-participant observer wrote a record of the lesson and made a note of learners' questions and answers in whole class oral exchanges. This provided essential backup to the tape recording that, while capturing the teacher, did not always record clearly the contributions of the learners. The observer also recorded verbatim any notes written on the board and listed any teaching aids used. Lastly, copies of the sections of prescribed textbooks used during the lesson were obtained. While these collection methods did not capture completely the peer interaction within groups of learners, an otherwise comprehensive set of records of lessons was obtained. Triangulation of the data from the different sources increased the validity of the lesson descriptions.

Each tape was transcribed verbatim and analysed for reference to a prescribed textbook. Occasionally teachers used other resources to support learning. For instance, one or two lessons used handouts for practical work or homework exercises. However, these situations were rare. A few learning activities were based on instructions written on the blackboard. These instances were included in this study only if the handouts or task instructions were taken from a prescribed textbook.

The content of the five prescribed science textbooks for the classes observed was analysed for the occurrence of various genres of writing as identified by Martın (1993) and as applied to student writing by Keys (1999). They were also analysed for the different types of learning activities they support in line with the methodology for textbook analysis developed by Peacock and Gates (2000).

The analysis of instances of textbook usage draws on the notion that the school textbook may be perceived as an example of a register of communication (Halliday \& Hasan, 1976), t.e. 'a set of meanings and configurations of semantic 


\section{$114 F$. Lubben et al.}

patterns, that are typically drawn upon in specific conditions, along with the words and structures that arc used in the realisation of these meanings'. Halliday and Hasan (1976) identify three compenents of such a register. First, its field determmes the aspect of the context that is being reinforced by the mode of communication. In this study the field is translated as the pedagogic purpose of the reference to the textbook. Secondly, the register's mode describes the language genre employed (Swales, 1990). In this study the mode is interpreted as the genre of the section of the text being referred to. Lastly, Halliday and Hasan (1976) identify the register's tenor describing the form of social interaction accompanying a communication, in this case accompanying the reference to the textbook in class.

By cross-checking with observation records where required, each instance of textbook reference was classified in terms of aspects of field, mode and tenor. Here, grounded theory was used to determine descriptors of different aspects of each. Seven descriptors for classifying aspects of field, four descriptors for the mode and three descriptors for the tenor were developed. This process involved independent analysis by all authors of several sample lessons followed by discussion to agree the descriptors for each aspect. There followed further independent analysis of the lesson transcripts to code each instance of a textbook reference in terms of an aspect of each of field, mode and tenor. Comparison of the analyses and the easy resolution of the few (10\%) differences that emerged demonstrated the reliability of the analysis. For each lesson, the frequency of references to textbooks, the originator of the reference (teacher or leamer) were determined along with the frequencics of each aspect of field, mode and tenor.

\section{Results}

\section{Textbooks in Use in Science Classes}

A standard science textbook was prescribed for use by each of the classes observed. The Junior Secondary classes used locally written textbooks: Life Science for Namibia, Grade 10 (Nott et al., 1997) and Physical Science for Namibia, Grade 10 (Curry et al., 200) for Biology and Physical Science, respectively The Senior Secondary classes used imported texts: GCSE Biology', 2nd edn (MacKean, 1995), Chemistry, Made Clear, GCSE edition (Gallagher \& Ingram, 2000) and Physics for IGCSE (Foxcroft \& Lewis, 1996), the first for Biology and the last two for Physical Science. Table I provides an analysis of the text genres and teaching activities supported by these textbooks.

All textbooks are remarkably similar in their text genres. They all provide large sections written in three of the five scientific genres identified by Martin (1993), t.e. the report, explanation and experiment genres. All textbooks extensively use the report genre, characterised by a style using generic participants, timeless verbs and a proliferation of the verbs to be and to have. Definitions, classifications and the presentation of facts (i.e. the WHAT of science) are 
TA13.1: I. Text genres and teaching actrities supported by prescribed texthooks

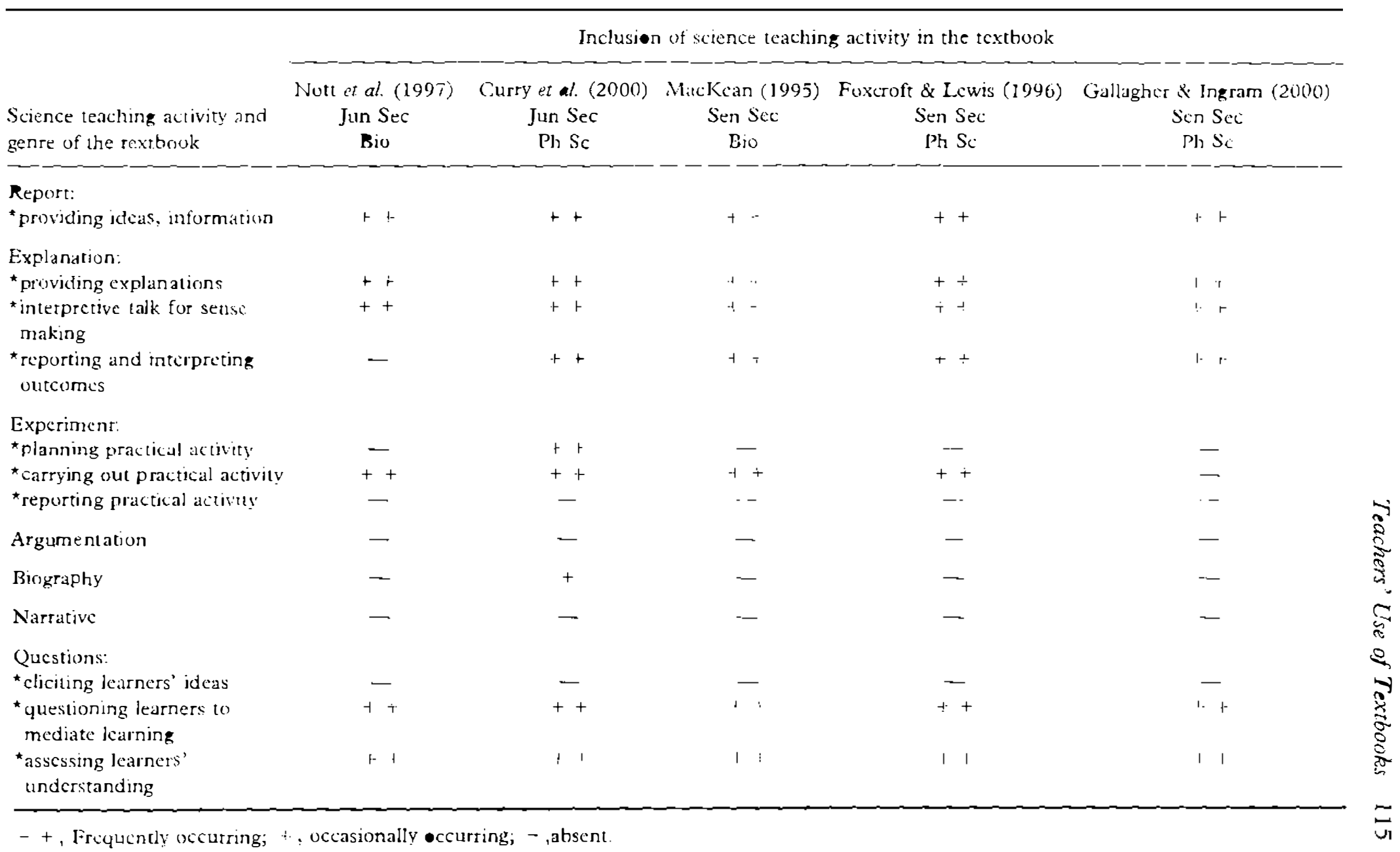


examples of the report genre frequently used in all the textbooks. This approach is not that unusual in science textbooks that most commonly present the subject as an uncontentious body of knowledge.

Unsurprisingly, all the textbooks use the explanation genre extensively, characterised by a style using generic participants, timeless and mainly action verbs, with the presentation of an explanation in a logical order. Cause-andeffect description, observation and hypothesis, interpretations of outcomes and the presentation of explanatory relationships are examples of the explanation genre used in all the textbooks (i.e. the WHY of science). All the textbooks except Nott et al. (1997, for Junior Biology) provide summaries and interpretations of suggested practical activities.

All textbooks also use the experment genre characterised by a set of sequential procedures for a practical activity and a fixed format (aim/method/ apparatus/results/conclusions) for recording this. Only Curry et al. (2000, for Junior Physical Science) provides open-ended tasks for which learners need to do the planning themselves. The textbook by Gallagher and Ingram for Senior physical science classes is unusual in that it provides practical tasks, a set of example observations and interpretations of these observations.

None of the textbooks use the argumentation genre characterised by the presentation of contrasting observations or reasoning to support different conclusions. The biography genre, i.e. historical descriptions of personal experiences, was used infrequently. Curry et al. (2000, for Junior Physical Science) provides accounts of famous scientists, often accompanied by a portrait, but these accounts focus solely on their discoveries and do not touch on their life experiences nor the reactions to their discoveries.

Only one of the two expressive genres is used in the textbooks. The narratıve genre, (typically a story about an everyday event in non-scientific language) does not feature in any of the textbooks. However, all the textbooks include questions as a genre. These would seem to be included to help to develop and to assess learners' understanding, but not in order to determine learners' previous knowledge of a topic to be dealt with.

\section{The Use of Textbooks in Science Lessons}

Table II indicates the number of times the teachers or their learners made references to the prescribed textbook. If learners were referred to handouts, not taken from the textbook or exercises not included in the textbook, these instances have not been included in the analysis.

Table II indicates that in the science lessons observed, the greatest number of refcrences to a textbook was in Junior Secondary biology classes but that, on average, reference was made to a prescribed textbook less than twice (1.7 references) per lesson. It is somewhat surprising that in more than a quarter of the observed lessons (eight of 29) the textbook was not referred to at all. Such lessons were not limited to spccific tcachers nor schools but were proportionally higher in Senior Secondary classes (about 40\%) than in Junior Secondary 
TABLE II. Frequency of rcferenccs to rextbooks in lessons

\begin{tabular}{|c|c|c|c|}
\hline $\begin{array}{l}\text { Science subject } \\
\text { and educational level }\end{array}$ & $\begin{array}{l}\text { Number of observed } \\
\text { lessons (number of } \\
\text { Icssons without } \\
\text { refcrencc to textbook) }\end{array}$ & $\begin{array}{l}\text { Frequency of } \\
\text { refcrcncc to textbook } \\
\text { ovcr all lessons }\end{array}$ & $\begin{array}{l}\text { Average frequency } \\
\text { of reference to } \\
\text { tcxtbook per lessons }\end{array}$ \\
\hline $\begin{array}{l}\text { Biology: } \\
\text { Junior Sccondary }\end{array}$ & $6(-)$ & 16 & 2.7 \\
\hline $\begin{array}{l}\text { Biology: } \\
\text { Senior Secondary }\end{array}$ & $9(3)$ & 13 & 1.4 \\
\hline $\begin{array}{l}\text { Physical Scicnec: } \\
\text { Junior Sccondary }\end{array}$ & $5(1)$ & 8 & 1.6 \\
\hline $\begin{array}{l}\text { Physical Science: } \\
\text { Scnior Secondary }\end{array}$ & $9(4)$ & 12 & 1.3 \\
\hline Total & $29(8)$ & 49 & 1.7 \\
\hline
\end{tabular}

classes $(10 \%)$. This high proportion of non-use of a textbook causes the average frequency of textbook reference per lesson to be considerably lower at Senior Secondary (1.4) than at Junior Secondary level (2.2).

The Field of the Use of Textbooks in Class

Table III presents frequencies of the aspects of the 'field' of textbook references as their pedagogıc purposes. Grounded theory was used to identify the seven

T.131.1: III Frequenctes of types of pedagogıc purpuses of tcxtbook use in Icssons

\begin{tabular}{|c|c|c|c|}
\hline Typc of pedagogic purpose & $\begin{array}{l}\text { Frcquency of use in } \\
\text { Junior Sccondary } \\
\text { lessons }(n=24)\end{array}$ & $\begin{array}{l}\text { Frequency of use in } \\
\text { Senior Sccondary } \\
\text { lessons }(n=25)\end{array}$ & $\begin{array}{l}\text { Total frequency } \\
\text { of use }(n=49)\end{array}$ \\
\hline $\begin{array}{l}\text { 1. To provide diagrams to support } \\
\text { exposicion or questions. }\end{array}$ & 10 & 11 & 21 \\
\hline $\begin{array}{l}\text { 2. To provide authority to teacher's } \\
\text { exposition or mediate for differing } \\
\text { vicws of Icarncrs. }\end{array}$ & 4 & 7 & 11 \\
\hline $\begin{array}{l}\text { 3. To read to consolidate or explore } \\
\text { theoretical knowledge. }\end{array}$ & 5 & 3 & 8 \\
\hline $\begin{array}{l}\text { 4. To guide practical activitics and } \\
\text { the record of thesc activities. }\end{array}$ & 5 & - & 5 \\
\hline 5. To set the teaching agcnda. & 1 & 2 & 3 \\
\hline $\begin{array}{l}\text { 6. To pronide a source for learnces } \\
\text { to cop! text ot diagrams froms. }\end{array}$ & 1 & 2 & 3 \\
\hline $\begin{array}{l}\text { 7. To provide questions for learnars } \\
\text { to ansiver. }\end{array}$ & - & 3 & 3 \\
\hline
\end{tabular}




\section{F. Lubben et al.}

different aspects listed in the first column of the table. The remaining columns of this table show the frequencies of the various pedagogic purposes of references textbook that were recognised in Junior Secondary and Senior Secondary science classes, respectively. It should be noted that some textbook references have been seen to serve more than one pedagogic purpose. Thus, the total frequency of pedagogic purposes exceeds the total number of textbook references.

Table III shows that over $40 \%$ of the references to textbooks were specifically to diagrams to support the teacher's exposition or to form a basis for the teacher's questions. This was equally so at Junior and Senior Secondary level. For example, in one lesson the teacher made reference to a textbook chart with the frequencies and sources of different types of waves as a basis for discussing the application of these waves. In anothcr lesson, the teacher drew attention to a table with metals sequenced according to their reactivity to ask about products of different metal-salt reactions. In a further lesson a teacher asked learners to look at a diagram of the heart and asked them to explain why specific tissues are thick and others thin.

Just over $20 \%$ of the instances of textbook reference were to cite the textbook as the source of authority, either to back up the exposition of the teacher, or to help answer a learner's question. This happened more frequently at Senior than at Junior Secondary level. For instance, at the end of a practical lesson aimed at determining the density of different substances, the teacher commented on the findings of a group as follows:

$\mathrm{T}$ I think this is correct. But the density of water seems to be ... eh? Is there anybody here with a book? Any book?

I thınk the density of water ..., I think it is ONE. Not 1.7 but 1.

Another example is the situation where learners could not agree on the characteristics of arteries and veins:

$T W^{\prime}$ hat is the difference between the arteries and the veins?

L An artery is having a thin wall.

$\mathrm{T}$ An artery has a thin wall. Are you all agreeing, that an artery has a thin wall?

L No.

T You say no. What is your idea?

L A thick wall and a small surface area.

$T$ A small surface area, a small room in it. Okay. Look in those diagrams in your book.

On the right side of your body, the left side of your book. There are two drawings of the arteries and the veins.

$T$ So the artcry is having a thick wall, becausc? Why is it having a thick wall?

About $15 \%$ of the references to the textbook related to homework. Herc, the learners werc directed to the textbook either to consolidate theory dealt with in 
the lesson or to explore content to be covered in the following lesson. No major differences between Junior and Senior Secondary level were apparent.

About $10 \%$ of the references to the textbook were to instructional worksheets for practical work photocopied from the textbook. This was unique to Junior Secondary lessons. The worksheets listed the steps for the practical procedures and included tables to record the observations. Thus, the textbook was used to gunde practical work and provide a structure for the record of the practical report.

Occasionally, the teacher referred to the textbook merely to identify the topic or the chapter that related to the lesson. The purpose was to provide a point of reference for the learners and set an explicit agenda for the lesson. Similarly, learners were occasionally instructed to copy text or a diagram, or to answer comprehension questions provided at the end of a textbook chapter as a way of consolidating their learning.

\section{The Mode of Textbooles Lised m Class}

The mode of tcxtbook use is equated here with the genre of the section of text referred to in the textbook. The first column of Table IV shows the three scientific genres (report, explanation, experiment) and one expressive genres (questioning) present in the textbooks (see Table I). The remaining columns of the table show the frequencies of reference to these different genres of text in Junior and Senır Secondary science classes, respectively.

Tablc IV shows that the sections of the textbook to which learners were referred were written mainly in the report genre (e.g. factual lists, classifications, descriptors and definitions) and the explanation genre (logically sequenced descriptions emphasising the inter-relationship of components including causeeffect relationships). About $40 \%$ of the textbook references were to passages written in each of these genres. There was no difference between the two educational levels.

Table IV also shows that text written in the experiment genre (using instructions and a prescribed format for reportung observations) was referred to

TABLF IV. Frcquencies of genres of tcxt in tcxtbooks referred to in lessons

\begin{tabular}{lccc}
\hline Genrc & $\begin{array}{c}\text { Frequency of } \\
\text { rcference in } \\
\text { Junior Secondary } \\
\text { Icssons }(n=24)\end{array}$ & $\begin{array}{c}\text { Frequency of } \\
\text { reference in } \\
\text { Scnior Secondary } \\
\text { Icssons }(n=25)\end{array}$ & $\begin{array}{c}\text { Total } \\
\text { frequency of } \\
\text { referencr: }(n-49)\end{array}$ \\
\hline Scientific: report only & 10 & 11 & 21 \\
Sicientific: explanation (with report) & 8 & 10 & 5 \\
Scientific: experiment & 5 & - & 5 \\
Expressivi:: questioning & 1 & 4 & 5 \\
\hline
\end{tabular}




\section{F. Lubben et al.}

in only $10 \%$ of the instances and that this only occurred in Junior Secondary classes. Lastly, in another $1 \%$ of the references to the textbook the focus was on text written in the questioning genre (the format for standard exercises). This occurred mainly at the Senior Secondary level.

\section{The Tenor of the Use of Textbooks in Class}

The tenor of textbook usage describes the nature of the social interaction through which a reference to a textbook is transacted. We identified, through grounded theory analysis, different forms of reference made by the teacher or a learner. The textbook was referred to for use by either the whole class, a group in the class, or an individual and for use at school or at home. Table $V$ present frequencies of the occurrence of the different social interactions related to textbooks use.

Table $\mathrm{V}$ indicates that the class teachers made almost all references to the textbooks (categories la-e). The few occasions where learners mentioned the textbook occurred at Junior Secondary level. In about $60 \%$ of the cases (category Ic), the teacher invoked whole-class usage of the textbook. In only $10 \%$ of the instances (category la) did the teacher direct individuals to the textbook (usually after they had asked a question, or provided an unacceptable response). In $15 \%$ of the cases (category $1 \mathrm{~d}$ ), the teacher referred to the textbook in order to set homework tasks that required learners to study individually.

TABLE V. Frcquencies of types of social interaction related to textbook use in lessons

\begin{tabular}{|c|c|c|c|}
\hline Type of sucial interactions & $\begin{array}{l}\text { Frequency } \\
\text { in Junior } \\
\text { Sccondary } \\
\text { lessons }(n=2-4)\end{array}$ & $\begin{array}{l}\text { Frequency } \\
\text { in Scnior } \\
\text { Secondary } \\
\text { lessons }\{n=25\}\end{array}$ & $\begin{array}{l}\text { Total } \\
\text { frequency } \\
(n=49)\end{array}$ \\
\hline $\begin{array}{l}\text { 1a. Teacher rufers to the textbook to be } \\
\text { used at school by individual learners. }\end{array}$ & ] & 4 & 5 \\
\hline $\begin{array}{l}\text { 1b. Teacher refers to the textbook to be } \\
\text { used at school by groups of learncrs. }\end{array}$ & 2 & ] & 3 \\
\hline $\begin{array}{l}\text { 1c. Teacher rcfers to the textbook to be } \\
\text { used at school by the whole class. }\end{array}$ & 14 & 16 & 30 \\
\hline $\begin{array}{l}\text { 1d. Teacher refers to the textbook to be } \\
\text { used at homc by individual lcarncrs. } \\
\text { 1c. Teacher refers to the textbook to be }\end{array}$ & 4 & 4 & 8 \\
\hline used at home by groups of learncrs. & -- & I & 1 \\
\hline $\begin{array}{l}\text { 2a. I camer refers to the textbook to be } \\
\text { used at school by individual learners. }\end{array}$ & 2 & - & 2 \\
\hline $\begin{array}{l}\text { 2d. I-carncr refers to the textbook to be } \\
\text { used at home by individual learners. }\end{array}$ & 1 & - & 1 \\
\hline
\end{tabular}




\section{Discussion}

The approach taken to analyse the classroom data collected in this study is one adapted from the systemic linguistic research tradition for analysis of textual material. Ours appears to be a unique application and one that has yielded insights into the use (and non use) of textbooks in support of classroom learning. The aspects of field (pedagogic purpose), mode (genre) and tenor (social interactions) all indicate aspects of teacher and learner engagement with textbooks, and thus categorise the dynamic of textbook usage. As such the analysis framework has proved to be a useful adaptation.

\section{Frequency of Using the Prescribed Texts in Classroom Teaching in Namibia}

The data show that the prescribed textbook was not referred to at all to support class activities nor to set homework in more than a quarter of all lessons observed (10\% of lessons at Junior Secondary and almost $40 \%$ of the lessons at Senior Secondary level). In view of the importance attached to the use of textbooks and their association with improvements in standards, as well as the financial investment associated with their purchase this is a disappointing and worrying observation. It is of particular concern when one notes that the learners in the senior classes were preparing for IGCSE examinations that determine their future prospects in education and employment. We have no evidence to suggest that teachers' failure to use the prescribed textbooks in class is due to the absence of the textbooks in school or of insufficient copies being available. The prescribed textbooks were noted to be in use in same grade classes taught by different teachers in the same school and in other lessons taught by the same teacher to the same class. This would indicate that use of the prescribed textbook in a lesson is a pedagogical decision made by the teacher and not a planning decision determined by the availability of resources.

This striking non-utilisation of textbooks (particularly with IGCSE classes) indicates a failure to capitalise on valuable learning aids and a wastage of the scarce financial resources that have been invested in their purchase It is unlikely that teachers are wilfully negligent with regard to their lack of reference to tcxthooks in class but that rather they are unskilled and lacking confidence in their use. If this is, indeed, the case then the return on the investment in textbooks could be increased considerably if teachers could be trained explicitly to teach with the aid of the prescribed textbooks as illustrated by case studies of the READ project in South Africa (Radebe, 2000). This need for training is further supported by the limited range of textbook usage.

The frequency of reference to a prescribed textbook in the remaining lessons is low. This may be a further reflection of the long established and persistently prevailing learning and teaching practice in many classrooms in Southern Africa of teacher oratory and elicitation through superficial and factual questioning (Rowell \& Prophet, 1990; Arthur, 1998). Traditional social relationships between teacher and learner project the teacher as an authority figure 


\section{$122 F$. Lubben et al.}

and the source of knowledge (Tabulawa, 1997). Such pedagogical styles do not lend thomselves to involving textbooks during class. Thus, any training schemes aimed at mproving the use of textbooks in classrooms, should simultaneously focus on changing the role of the teacher in the learning and teaching process. It is of interest that the Namibian Government policy on learning and teaching stresses I_tarner Centred Education (GRN, 1993) yet in the lcssons observed the data would suggest that this is not the reality.

Teachers' references to textbooks are much higher at the Junior Secondary than at the Senior Secondary level. This may well reflect the difference in the nature of these books. The textbooks for Junior Secondary level have been generated locally and are contextualised for the Namibian curriculum. As part of a massive post-independence in-service programme (Ottevanger $\&$ Benschop, 1995), Junior Secondary science teachers have contributed to the refinement of the textbooks and have been trained in the use of these textbooks (Tiikuua, 2000). This seems to support the vicw that teachers can bencfit greatly from approprate training in the use of the prescribed textbooks. It could thus be of considerable value to include a substantial module on the effective use of textbooks in the current upgrading programme (MASTEP) for mathematics and science teachers in Namibia.

\section{Purposes for Whach Textbooks are Used in Classroom Teaching}

It is reassuring that teachers referred learners to correctly drawn and labelled diagrams from a textbook to support their exposition and questioning, rather than an often hastily drawn and inaccurate version copied on to the board. However, the textbook was used infrequently for other text-based classroom activities, such as text comprehension, definition of terms, data interpretation, small group discussion tasks and practical activities. Neither is there evidence that the textbook was studied in class: the location where the teacher can discuss meanings and interpretations with learners, relate the content to the context, offer alternative explanations, and pose and answer questions raised by the text.

The use of the textbook for setting homcwork tasks and for the adjudication of learncrs' differing views suggests that teachers consider the textbook as an authoritative source of the expected science content knowledge (Luke et al., 1989), rather than a resource for lcarning activities. This limited view of the textbonk as a means of consolidating fixed knowledge conflicts with modern views of the nature of science as a body of developing and sometimes debatable knowledgc. It also limits its use to support learner-centred education (GRN, 1993) through which learners are encouraged to explore and challenge their understandings and develop critical thinking skills.

\section{Differences in the Use of Textbooks in Funior and Senior Classes}

The pedagogical purposes for which textbooks were used with Junior and Senior Secondary level classes differed only marginally. At Senior Secondary level the 
textbook was more often referred to as an arbiter for conflicting learner understandings, or for confirming the teacher's exposition. This is not unexpected as the teachers in the sample have not been traincd to teach at Senior Secondary level, and acknowvledge therr lack of confidence in content knowledge. Their uncertainty about science content and required syllabus depth may also explain the use of a textbook by Senior Secondary teachers for set exercises to cvaluate learners' understanding. Driscoll et al. (1994) point out that teachers who are unfamiliar with the content they have to teach often rely heavily on a prescribed textbook for their lesson preparation yet may not use the text in class. Indeed, Tjikuua (2000) notes that annotated textbooks are widely used for lesson preparation by teachers in Namibia.

The pattern of social interaction in which the textbook was involved was characterised by the teacher directing the whole class to specific sections in the textbook. In this regard, there was no difference between Junior and Senior Secondary lessons observed. Keeping in mind that, apart from the teacher, the textbook is the main learning resource available to the learners, it is of interest that so fow learners refer to the textbook. Whole-class textbook usage on teacher's instruction may be seen as an indicator of activity-based learning, and thus as one of the ways learner-centred education can be implemented in class (Dahlstrom, 1999). However, such use of the textbook does not support learner-centred education in the deeper sense, i.e. increasing opportunities for learners to take charge of their own learning (Zeichner \& Tabachnick, 1999).

\section{Conclusion}

The findings of this study indicate that the presence of a prescribed textbook in Namibian science classrooms is no guarantee for its efficient and imaginative usage in support of a policy for learner-centred education. Although there is evidence that the provision of textbooks is one of the most powerful tools in improving education in developing countries we still need to answer questions as to how this improvement is related to teachers' use of textbooks in class. Further research needs to identify why textbooks are uscd in the way they are and, where this is inappropriate, how best to educate teachers to use textbooks more effectively.

\section{Acknowledgements}

We wish to acknowledge the help of BEd students in the Department of Mathematics, Science and Sport Education at the University of Namibia who assisted with data collection. The study was carried out with the financial assistance of the British Council.

\section{RHFERE: YCES}

ARTHL:R, J. (1998) Instructional practices and the cultural construction of primary school teaching in Botswana, Comparatric Educanm, 34(3), pp. 313-326. 


\section{$124 F$. Lubben et al.}

Curky, N., Linow, K., SPlilimadx, H. \& TikUla, C. (2000) Physical Science for Namibia, Grade 10 (Windhock: Hcinemann).

1) a Crliz: A., Ge(trgie, 'Г., Gnahore, F., Kelakou, F., Mrnodica, P., Reais. A., Sehlabi, C \& SiMt(1), M. (2000) Financing Téxtbooks and Teuching Tramng Materials (London, ADEA/ DFIIS;

D.1H1.s[?(1.M1, L. (1999) Transforming teacher education for a democratic sucicty: the case of Namibia, Teactung E Teuht Eitucunon, 15; pp. 143\%155.

Deuscoll, M., Mo.tlikM, M., Dick, W. \& KirkY, E. (1 994) How does the textbook contribute to Icarning in a middle school sciencc class? Contemporary Educational Psychologr, 19, pp. $79-100$.

Foxcrofi, G.E. \& LEWIS, J.L. (1996) Physics for IGCSE (Oxford, Heinemann)

Gallagher, R. \& INGRaim, P. (2000) Chemistry Made Clear (Oxford, OUP).

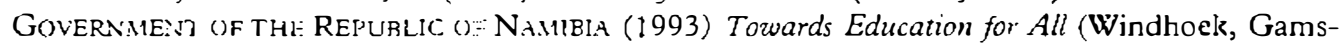
berg Macmillan).

GeverNmest of the Repciblic of Namibia (1999) Report of the Presidential Commission on Education, Cuture and Training, Volume 1 (Windhock, Gamsberg Macmillan).

HaGGaRTY, L. \& PfPIN, B. (2002) An investigation of mathematics textbooks and their usc in English, French and German classrooms: who gets on opportunity t• learn, Brtish Educaional Research fournal, 28(4), pp. 567-590.

HaLliDAY, M.A.K. \& Hasian, R. (1976) Cohesion in English (London, Longman)

Høwie, S.J. (2001) Mathematics and Sctence Performance in Grade 8 in South Africa 1998/1999 (Pretoria, Human Scienccs Rescarch Council).

Jorwso:, M. (1999) The declining usc of books in schools: the implication for cffective tcaching and learning, Forum, 41(3). pp. 115-118

KEARSI:Y, J. \& 'TURNER, S. (1999) Eraluating textbooks: the role of genre analysis, Research "n Science and Tichnological Education, 17(1), pp. 35-43

Kurs, C..W (1999; Kevitalizing mstructuon in scientitic genres connecting knowledge production with Writing to I.carn Sclence, Sclence Educallon, 83(2), pp. 115-130.

Kuн:s, T. (1970) The Structure of Screntific Revolutronj (Chicago, IL, University of Chicago Press)

LA.MeERT, D. (1999) Exploring thc usc of textbouks an Key Stage 3 Gcography classrooms: a small-scale siudy, Cutriculum foumal, 10(1), pp. 85-105.

LLKE, C., DE CASTELl, S. \& LUKE, A. (1989) Beyond critucism: the autherity of the schoolbook. In: S. DE CASTELl, A. LUKe \& C. LUKe (Eds) Language, Authority and Criticism, pp. 245-260 (I,ondon, Falmer Press).

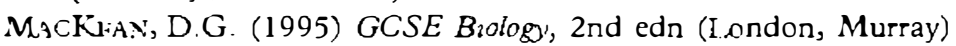

MARTI:, J.R. (1993) Litcracy in science: learning to handle text as technology, in: M.A.K. HAillDAY \& J.R. MARTIN (Eds) IVriting Science: literacy and discursive power, pp. 166-220 (Pittsburgh, PA, Pittsburgh Univcrsity Press).

MERRITT, M. (1992) Socialising multilingualism: determinants of code switching in Kenyan primary schools, foumal of Multicultural and Multilingual Development, 13(2), 103-121.

MiLNi:, C., G UUGH, N. \& Loving, C. (2002) Textbooks: the flower dissection, in J. W'ALLACF \& W. Lolibon (Eds) Dilemmas in Sezence and Education: perspectines on problems of practice, pp. 115-127 (London, Routlcdge).

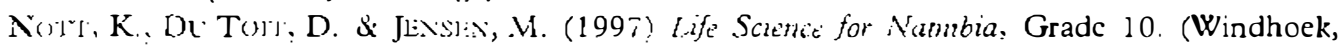
Longman).

OI.SON, D.R. (1989) On the language and authority of tcxtbooks, m: S DE CAs rill. A. LCKI: \&

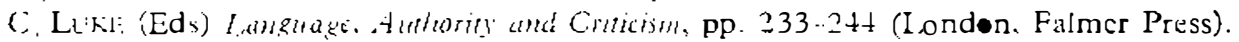

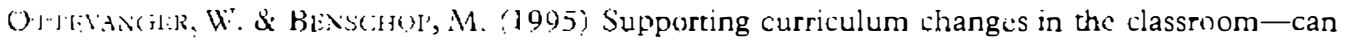

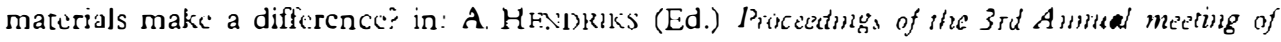
SAARMSE, C.ape Town, 19-23 January 1995, pp. 630-636

PEACOCK, A. \& Gitrls, S. (2000) Newly qualificd primary teachers' perceptions of the role of text matcrial in tcaching sciencc, Reserrch $" \prime$ Science and Tichnological Education, 18(2), pp. $155-171$ 
PRophet, B. \& TOW'Si, P. (1999) Pupils' understanding of some non-technical words in science, School Science Reviez', 81 (295), pp. 79-86.

Rabebe, T. (2000) Classroom libraries in South Africa, in: D. Rosenserg (Ed.) Books for Schools: improving access to supplementary reading materials in Africa, pp. 59--89 (Iondon, ADEA) DFID).

Rouret.l, P.I. \& Prophis, R. (1990) Curriculum-in-action: the 'practical' dimension in Rotswana classrooms, Intemationul Fonnal of Educational Development, 10(1), pp. 17-26.

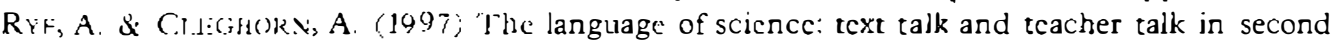
language sctings, in: M. SALNobirs (Ed.) Proceedrings of the Fifth Anmual Meting of SAARMSTE, 22-26 January 1997, Universtty of Witwatersrand, pp. 437-441.

STRAY, C. (1994) Paradigm regaincd: towards a historical sociology of the rextbook, funtral of Curriculum Sudres; $26(1)$, pp. 1-29.

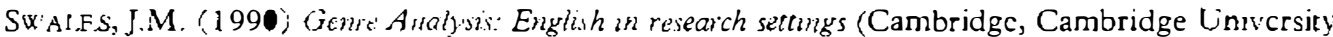
Press).

Tablilaifa, R. (1997) Pedagogical classroom practice and the social context: the casc of Botswana, Interrational foumtal of Educational Development, 17(2), pp. 189-204.

TIIKLitA, C. (2000) Science Education Reform in Namibra, paper presented at workshop Secondary Science Education for Development, 15-19 April 2000. Available at: http:/l wwwl worldbank.org/education/scied/Training (accessed 21 October 2001).

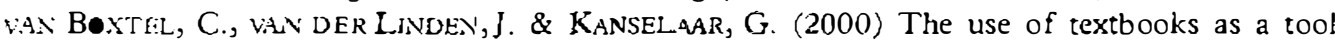
during collaborative physics learning, Joumal of Expermental Education, 69(1), pp. 57-76

V.Air GraAN, M., TJipLisi, G. \& DANCZYY, P. (2002) Monitoring curriculum reform and implementation in the upper primary phase of formal schooling, m: K. LEGESSE, P. WAIN.AIN A, R. AUALA, A. SCOTY \& M. Burrows (Eds) Issues in Education. occasional publication of the Faculty of Education, pp. 40-58 (Windhoek; UNAM).

VERSPOOR, A. (1991) 'Twenty years of World Bank support for Basic Education: presentation and cvaluation, Prospects, 21(3), pp 313-329

Witrsox; R. (2000) Relationstup Betzeen School Book Spending and School Results, Centrc for Successf ul Schwols, Lnwersit: of Kcelc. Availablc at: hetp://www.books-raise-scandards.co.uk

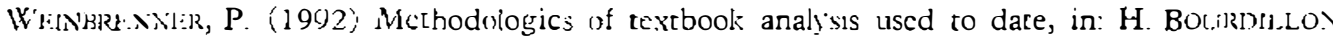
(Ed.) Hastory and Social Studies-methodologies of texthook anala'szi, pp. 21-34 (Amsterdam, Swcts \& Zeitlinger).

Z.4HORIK, J. (1991) Teaching stylc and textbooks, Teachmy \& Teacher Education, 7(2), pp $185-196$

Zeichi:LR, K. \& ГABACHNick,B. (1999) Participatory development and teacher education reform in Namibia, in: K. ZFichNer \& L. DAhLsTr@M (Eds) Democratic Teacher Education Reform in Africa, pp. 207-221 (Windhoek, Gamsberg Macmillan). 